Wahana Didaktika Vol. 18 No.2 Mei 2020 : 146-156

\title{
ANALISIS SOAL TIPE HIGHER OTHER THINKING SKILLS (HOTS) PADA TES OBJEKTF PILIHAN GANDA USBN BAHASA INDONESIA SD/MI
}

\author{
Oleh: Nela Oktarina, Dian Nuzulia Armariena \\ (Universitas Sebelas Maret, Univesitas PGRI Palembang) \\ Email: nelaoktarina@student.uns.ac.id, diannuzulia@univpgri-palembang.ac.id
}

\begin{abstract}
Abstrak
Penelitian ini bertujuan untuk mengetahui bentuk soal tipe Higher Other Thinking Skills (HOTS) pada teks objektif pilihan ganda USBN bahasa Indonesia SD/MI tahun pelajaran 2018/2019. Penelitian ini menggunakan metode deskriptif kualitatif dengan teknik analisis isi. Sumber data penelitian ini berupa butir-butir soal USBN Bahasa Indonesia SD/MI tahun pelajaran 2018/2019 yang dikeluarkan oleh Dinas Pendidikan Kota Madiun. Teknik pengambilan sampel dalam penelitian ini adalah purposive sampling. Teknik pengumpulan data penelitian menggunakan teknik pustaka dengan cara menyimak, mencatat, serta mengumpulkan data atau menemukan fakta-fakta yang kemudian dijadikan sumber data yang akan dianalisis. Hasil dari penelitian terhadap 20 butir soal soal objektif pilihan ganda, maka diperoleh dua belas butir soal yang termasuk dalam kriteria penilaian baik, satu soal termasuk dalam kriteria cukup baik, dua soal termasuk dalam kriteria kurang baik, dan lima soal termasuk kriteria tidak baik.
\end{abstract}

Kata Kunci: HOTS, Tes Objektif, Pilihan Ganda

\section{ANALYSIS OF HIGHER OTHER THINKING SKILLS (HOTS) TYPE OF TYPE ON USBN MULTIPLE CHOICE OBJECTIVE TEST ENGLISH LANGUAGE / MI}

\begin{abstract}
This study aims to determine the form of the type Higher Higher Thinking Skills (HOTS) in the objective text of multiple choice USBN Indonesian SD / MI in the academic year 2018/2019. This research uses descriptive qualitative method with content analysis technique. The data source of this research is in the form of questions about USBN Indonesian SD / MI in 2018/2019 academic year issued by the Madiun City Education Office. The sampling technique in this study was purposive sampling. Research data collection techniques using library techniques by listening, taking notes, and collecting data or finding facts which are then used as sources of data to be analyzed. The results of a study of 20 multiple choice objective items, twelve items were included in the good assessment criteria, one item included in the criteria of being good enough, two questions included in the criteria of inadequate, and five questions included in the criteria of not good.
\end{abstract}


Analisis Soal Tipe.... (Nela Oktarina, Dian Nuzulia Armariena)

Keywords: HOTS, Objective Test, Multiple Choice

\section{A. PENDAHULUAN}

Pendidik dalam kegiatan belajar mengajar tidak hanya dituntut untuk terampil. Tetapi, guru juga harus memiliki kemampuan untuk membuat atau mengembangkan alat evaluasi hasil belajar peserta didik. Evaluasi merupakan suatu penilaian yang dilakukan untuk melihat bagaimana proses yang terjadi serta untuk melihat telah tercapai atau belum tujuan pembelajaran yang telah dirumuskan. Alat yang digunakan untuk melakukan evaluasi adalah instrumen. Instrumen merupakan alat yang digunakan untuk menilai seberapa jauh kemampuan siswa dalam memahami materi pelajaran yang telah disampaikan oleh guru atau pendidik. Dalam proses pembelajaran instrument yang sering digunakan oleh pendidik adalah jenis instrument tes.

Tes adalah suatu jenis instrumen yang terdiri dari serangkaian tes yang harus dilakukan atau dilaksanakan oleh pendidik. Seperti yang dikemukakan oleh Sudaryono (2012:40) bahwa tes merupakan himpunan pertanyaan yang harus dijawab dan ditanggapi atau tugas yang harus dilaksanakan oleh orang yang dites. Tes dapat juga diartikan sebagai cara yang digunakan atau prosedur yang perlu ditempuh dalam rangka pengukuran dan penilaian di bidang pendidikan yang berbentuk pemberian tugas atau serangkaian tugas atau perintah-perintah yang harus dikerjakan.

Proses belajar mengajar memiliki serangkaian proses, dimana instrumen tes ini menjadi alat ukur untuk melihat capaian peserta didik dalam memahami materi pelajaran atau keberhasilan pendidik dalam proses belajar mengajar. Secara umum, tes diklasifikasikan menjadi beberapa golongan seperti yang di ungkapkan oleh Ratnawulan dan Rusdiana (2015:193) menjelaskan bahwa ada beberapa jenis tes yang sering digunakan dalam proses pendidikan, salah satunya adalah tes sumatif. Tes sumatif merupakan suatu tes yang dilakukan setelah serangkaian proses belajar mengajar selesai. Menurut Arikunto (2012:55) menjelaskan bahwa Tes sumatif dilaksanakan setelah berakhirnya pemberian sekelompok atau 
sebuah program yang lebih besar. Di sekolah, tes formatif dapat disamakan dengan ulangan harian, sedangkan tes formatif dapat disamakan dengan ulangan umum yang biasanya dilaksanakan pada tiap akhir semester.

Tes sumatif ini dilakukan dengan tujuan untuk melihat bagaimana capaian peserta didik dalam proses pembelajaran, sehingga pendidik mendapatkan hasil apakah peserta didik ini dapat lanjut pada pengajaran berikutnya. Majid (2011:196) mengemukakan fungsi tes sumatif yaitu untuk mengukur keberhasilan peserta didik secara menyeluruh. Hasil penilaian sumatif digunakan antara lain sebagai penentuan kenaikan kelas, kelulusan sekolah, dan sebagainya. Soal tes sumatif biasanya berupa tes tertulis yaitu tes objektif.

Tes objektif merupakan tes yang pilihan jawaban dibutuhkan sudah ada, tes objektif ini memiliki beberapa golongan salah satunya tes pilihan-ganda. Pilihanganda merupakan suatu tes yang difasilitasi dengan beberapa kemungkinan jawaban yang dapat dipilih. Menurut Zulmiati (2017:3), tes yang baik untuk mengevaluasi hasil belajar siswa harus bersifat objektif agar teruji validitas dan reabilitasnya. Bentuk tes yang paling sering digunakan adalah bentuk tes objektif pilihan ganda, bentuk tes pilihan ganda ini terdiri dari beberapa pertanyaan dengan menghadirkan beberapa pilihan jawaban, dari beberapa pilihan jawaban tersebut hanya satu yang tepat.

Sesuai dengan perkembangan yang ada, peserta didik dituntut untuk berpikir. Bagaimana siswa meningkatkan kemampuan berpikirnya dalam menjawab soal-soal atau tes yang diberikan oleh pendidik. Pendidik juga dituntut untuk mengembangkan soal-soal yang dapat meningkatkan kemampuan berpikir peserta didik, sebagai solusi makan digunakanlah kriteria pengembangan Higher Order Thingking Skills (HOTS). Menurut Presseisen (dalam Devi, 2011) menyatakan bahwa HOTS (High Order Thinking Skills) atau keterampilan berpikir tingkat tinggi dibagi menjadi empat kelompok, yaitu pemecahan masalah, membuat keputusan, berpikir kritis dan berpikir kreatif. Dalam hal ini lebih ditekankan kepada berpikir kritis. Proses pembelajaran yang berorientasi pada pada kemampuan tingkat tinggi atau Higher Order Thingking Skills (HOTS) 
diterapkan sebagai upaya untuk meningkatkan kemampuan berpikir peserta didik dan kualitas lulusan.

Berpikir tingkat tinggi terjadi jika seseorang memperoleh informasi baru dan disimpan dalam memori dan saling berkaitan atau menata ulang informasi tersebut untuk mencapai tujuan atau menemukan kemungkinan jawaban dalam kondisi yang membingungkan (Lewis \& Smith, 1993). Sedangkan, Brookhart (2010) mengatakan bahwa kemampuan berpikir tingkat tinggi dikategorikan kedalam tiga bagian, yaitu sebagai bentuk transfer hasil belajar, sebagai bentuk nerpikir kritis, dan sebagai proses pemecahan masalah. Berdasarkan dua pendapat diatas, penerapan Higher Order Thingking Skills (HOTS) sangat penting untuk diterapkan, mengingat siswa tidak hanya memiliki kemampuan berpikir yang baik dalam dunia pendidikan saja, melainkan siswa juga dapat memberikan solusi atau memecahkan permasalahan yang ditemukannya dalam lingkungan kehidupan sehari-hari.

Setiap siswa pada dasarnya pasti mampu berpikir, hanya saja siswa belum mampu menggunakan kemampuan berpikirnya dengan baik dan maksimal. Leonard (2013) mengemukakan bahwa pada dasarnya setiap tindakan yang dilakukan oleh manusia merupakan buah dari berpikir, tetapi tidak semua manusia ingin menggunakan otaknya untuk berpikir hal-hal yang baik. Dapat dikatakan bahwa jika siswa pasif dalam mengikuti proses pembelajaran itu sebagai tanda bahwa siswa kurang mendayagunakan proses kemampuan berpikirnya.

Kemampuan berpikir tingkat tinggi atau HOTS (High Order Thinking Skills) merupakan bagian utama dari Taksonomi Bloom Hasil Revisi Anderson dan Krathwol yang meliputi tingkatan menganalisis (C4), tingkatan mengevaluasi (C5) dan tingkatan mencipta (C6). Selain itu, tingkatan mengingat (C1), tingkatan memahami (C2) dan tingkatan mengaplikasikan (C3) sebagai bagian dari kemampuan berpikir tingkat rendah atau LOTS (Low Order Thinking Skillss).

Sesuai dengan perkembangan ilmu pengetahuan, maka soal-soal yang akan diujikan untuk tingkat SD harus memiliki tingkatan yang meliputi High Order Thingking Skills (HOTS). Pendidik juga harus memahami perbedaan soal kategori 
Low Order Thingking Skills (LOTS) melalui kata kerja operasionalnya. Komponen HOTS meliputi tingkatan C4 menganalisis (analyzing), C5 mengevaluasi (evaluating), C6 mencipta (creating). Sedangkan komponen LOTS meliputi $\mathrm{C} 1$ mengingat (remembering), $\mathrm{C} 2$ memahami/mengerti (understanding), C3 menerapkan (applying).

\section{B. METODOLOGI PENELITIAN}

Penelitian ini menggunakan metode deskriptif kualitatif dengan teknik analisis isi atau content analysis. Moleong (2007:6) mengemukakan bahwa penelitian kualitatif sebagai penelitian yang bermaksud untuk memahami fenomena tentang apa yang dialami oleh subjek penelitian seperti perilaku, persepsi, motivasi, tindakan, dll. Secara holistik dan dengan cara deskripsi dalam bentuk kata-kata dan bahasa, pada suatu konteks khusus yang alamiah dan dengan memanfaatkan berbagai metode alamiah.

Sumber data penelitian ini berupa butir-butir soal USBN Bahasa Indonesia SD/MI tahun pelajaran 2018/2019 yang dikeluarkan oleh Dinas Pendidikan Kota Madiun. Teknik pengambilan sampel yang digunakan dalam penelitian ini adalah purposive sampling. Teknik pengumpulan data penelitian menggunakan teknik pustaka. Teknik pustaka ini dilakukan dengan cara menyimak, mencatat, serta mengumpulkan data atau menemukan fakta-fakta yang kemudian dijadikan sumber data yang akan dianalisis. Penelitian ini dilakukan dengan cara menganalisis soal tes objektif pilihan ganda USBN Bahasa Indonesia SD/MI tahun pelajaran 2018/2019 dengan menemukan fakta-fakta yang kemudian dianalisis menggunakan teori yang ada.

\section{HASIL PENELITIAN DAN PEMBAHASAN}

Setelah melakukan penganalisisan pada soal tes objektif pilihan ganda USBN bahasa Indonesia SD/MI tahun pelajaran 2018/2019 mengenai analisis HOTS (High Order Thinking Skills), maka ditemukan 12 soal yang memenuhi 
kriteria pengembangan soal HOTS (High Order Thinking Skills) dan 8 soal yang tidak memenuhi kriteria pengembangan soal HOTS (High Order Thinking Skills). Kemudian setelah dianalisis kesesuaiannya dengan kriteria pengembangan soal HOTS (High Order Thinking Skills).

Langkah selanjutnya yang peneliti lakukan adalah menilai tingkat kesesuaiannya. Dari keseluruhan butir soal yang sudah dianalisis tadi dengan menggunakan pedoman analisis berbentuk kriteria pengembangan soal HOTS (High Order Thinking Skills), dapat diketahui soal mana saja yang dinilai baik, cukup baik, kurang baik, atau tidak baik. Dari 10 soal USBN bahasa Indonesia SD/MI tahun pelajaran 2018/2019 yang telah dianalisis dipaparkan dalam tabel di bawah ini sebagai berikut.

Tabel 1 Analisis Tes Objektf Pilihan Ganda

USBN Bahasa Indonesia SD/MI Tahun Pelajaran 2018/2019

\begin{tabular}{|c|c|c|c|c|}
\hline $\begin{array}{c}\text { Nomor } \\
\text { Soal }\end{array}$ & Kriteria & $\begin{array}{c}\text { Tingkat kognitif dan bentuk } \\
\text { pertanyaan dalam soal USBN SD/MI } \\
\text { tahun pelajaran } 2018 / 2019\end{array}$ & Penilaian & Nilai \\
\hline 1 & LOTS & $\begin{array}{l}\text { C2- Memahami (Understanding) } \\
\text { Memahmi makna dari kata "garansi" } \\
\text { dalam sebuah teks }\end{array}$ & $\begin{array}{c}\text { Kurang } \\
\text { baik }\end{array}$ & 1 \\
\hline 2 & LOTS & $\begin{array}{l}\text { C2- Memahami (Understanding) } \\
\text { Mengidentifikasi sinonim dari kata } \\
\text { "kejadian" dalam sebuah teks }\end{array}$ & $\begin{array}{c}\text { Kurang } \\
\text { baik }\end{array}$ & 1 \\
\hline 3 & LOTS & $\begin{array}{l}\text { C2- Memahami (Understanding) } \\
\text { Mengidentifikasi pernyataan yang } \\
\text { mengandung informasi yang sesuai } \\
\text { dengan paragraf }\end{array}$ & $\begin{array}{c}\text { Kurang } \\
\text { baik }\end{array}$ & 1 \\
\hline 4 & HOTS & $\begin{array}{l}\text { C4- Menganalisis (Analyzing) } \\
\text { Menguraikan jawaban pertanyaan yang } \\
\text { sesuai dengan sebuah kalimat } \\
\text { "Bagaimana pengaruh jatuhnya } \\
\text { Konstantinopel ke Turki Utsmani" }\end{array}$ & Baik & 4 \\
\hline 5 & HOTS & $\begin{array}{l}\text { C4-Menganalisis (Analyzing) } \\
\text { Menguraikan kalimat utama yang } \\
\text { terdapat dalam teks }\end{array}$ & Baik & 4 \\
\hline 6 & HOTS & C4- Menganalisis (Analyzing) & Baik & 4 \\
\hline
\end{tabular}




\begin{tabular}{|c|c|c|c|c|}
\hline $\begin{array}{l}\text { Nomor } \\
\text { Soal }\end{array}$ & Kriteria & $\begin{array}{c}\text { Tingkat kognitif dan bentuk } \\
\text { pertanyaan dalam soal USBN SD/MI } \\
\text { tahun pelajaran } 2018 / 2019\end{array}$ & Penilaian & Nilai \\
\hline & & $\begin{array}{l}\text { Menguraikan kalimat penjelas yang } \\
\text { terdapat dalam teks }\end{array}$ & & \\
\hline 7 & HOTS & $\begin{array}{l}\text { C4- Menganalisis (Analyzing) } \\
\text { Menganalisis ide pokok yang terdapat } \\
\text { dalam teks }\end{array}$ & Baik & 4 \\
\hline 8 & HOTS & $\begin{array}{l}\text { C4- Menganalisis (Analyzing) } \\
\text { Menyimpulkan teks }\end{array}$ & Baik & 4 \\
\hline 9 & HOTS & $\begin{array}{l}\text { C4- Menganalisis (Analyzing) } \\
\text { Mendefinisikan pernyataan yang sesuai } \\
\text { dengan teks }\end{array}$ & Baik & 4 \\
\hline 10 & LOTS & $\begin{array}{l}\text { C3- Mengaplikasikan (Applying) } \\
\text { Mengklasifikasikan jenis paragraf }\end{array}$ & $\begin{array}{l}\text { Cukup } \\
\text { baik }\end{array}$ & 3 \\
\hline 11 & HOTS & $\begin{array}{l}\text { C4- Menganalisis (Analyzing) } \\
\text { Menguraikan jawaban yang sesuai } \\
\text { dengan pernyataan "apa yang akan } \\
\text { terjadi jika sirih merah tidak bermanfaat } \\
\text { bagi manusia" }\end{array}$ & Baik & 4 \\
\hline 12 & HOTS & $\begin{array}{l}\text { C4- Menganalisis (Analyzing) } \\
\text { Menguraikan persamaan dalam kedua } \\
\text { teks }\end{array}$ & Baik & 4 \\
\hline 13 & LOTS & $\begin{array}{l}\text { C1-Mengingat (Remembering) } \\
\text { Melengkapi data yang disajikan dalam } \\
\text { sebuah tabel yang rumpang sesuai } \\
\text { dengan jawaban yang berada dalam } \\
\text { sebuah teks }\end{array}$ & $\begin{array}{l}\text { Tidak } \\
\text { baik }\end{array}$ & 1 \\
\hline 14 & HOTS & $\begin{array}{l}\text { C4- Menganalisis (Analyzing) } \\
\text { Menguraikan pernyataan sesuai dengan } \\
\text { cerita }\end{array}$ & Baik & 4 \\
\hline 15 & HOTS & $\begin{array}{l}\text { C4- Menganalisis (Analyzing) } \\
\text { Menganalisis watak tokoh Kelingking } \\
\text { dalam cerita }\end{array}$ & Baik & 4 \\
\hline 16 & LOTS & $\begin{array}{l}\text { C2- Memahami (Understanding) } \\
\text { Memahami makna yang bercetak miring } \\
\text { pada cerita }\end{array}$ & $\begin{array}{l}\text { Kurang } \\
\text { baik }\end{array}$ & 2 \\
\hline 17 & HOTS & C4- Menganalisis (Analyzing) & Baik & 4 \\
\hline
\end{tabular}


Analisis Soal Tipe.... (Nela Oktarina, Dian Nuzulia Armariena)

\begin{tabular}{|c|c|c|c|c|}
\hline $\begin{array}{l}\text { Nomor } \\
\text { Soal }\end{array}$ & Kriteria & $\begin{array}{c}\text { Tingkat kognitif dan bentuk } \\
\text { pertanyaan dalam soal USBN SD/MI } \\
\text { tahun pelajaran } 2018 / 2019\end{array}$ & Penilaian & Nilai \\
\hline & & $\begin{array}{l}\text { Menentukan kesimpulan yang sesuai } \\
\text { dengan cerita }\end{array}$ & & \\
\hline 18 & LOTS & $\begin{array}{l}\text { C2- Memahami (Understanding) } \\
\text { Mengemukakan tema yang terkandung } \\
\text { dalam puisi }\end{array}$ & $\begin{array}{c}\text { Kurang } \\
\text { baik }\end{array}$ & 2 \\
\hline 19 & LOTS & $\begin{array}{l}\text { C1- Mengingat (Remembering) } \\
\text { Menjelaskan maksud pernyataan yang } \\
\text { dicetak tebal pada sebuah cerita }\end{array}$ & $\begin{array}{l}\text { Tidak } \\
\text { baik }\end{array}$ & 1 \\
\hline 20 & HOTS & $\begin{array}{l}\text { C4- Menganalisis (Analyzing) } \\
\text { Menentukan kesimpulan dari sebuah } \\
\text { cerita }\end{array}$ & Baik & 4 \\
\hline
\end{tabular}

Tabel 03. Jumlah dan Presentase soal USBN bahasa Indonesia SD/MI tahun pelajaran 2018/2019 yang trmasuk tipe soal LOTS dan HOTS

\begin{tabular}{|c|c|c|}
\hline Tingkat & Jumlah Soal & Presentase \\
\hline \multicolumn{3}{|l|}{ LOTS (Low Order Thinking Skills) } \\
\hline C1 - Mengingat (Remembering) & 5 & $25 \%$ \\
\hline C2 - Memahami (Understanding) & 2 & $10 \%$ \\
\hline C3 - Mengaplikasikan (Applying) & 1 & $5 \%$ \\
\hline $\begin{array}{l}\text { Total LOTS } \\
\end{array}$ & 8 & $40 \%$ \\
\hline \multicolumn{3}{|l|}{ HOTS (High Order Thinking Skills) } \\
\hline C4 - Menganalisis (Analyzing) & 12 & $60 \%$ \\
\hline C5 - Mengevaluasi (Evaluating) & 0 & $0 \%$ \\
\hline C6 - Mencipta (Creating) & 0 & $0 \%$ \\
\hline Total HOTS & 12 & $60 \%$ \\
\hline Total Keseluruhan & 20 & $100 \%$ \\
\hline
\end{tabular}

Berdasarkan hasil analisis terhadap 20 butir soal tes objektif pilihan ganda USBN bahasa Indonesia SD/MI tahun pelajaran 2018/2019 ditemukan sebanyak 12 soal yang termasuk kategori soal tipe HOTS dan 8 soal yang termasuk kategori soal tipe LOTS. HOTS atau yang lebih dikenal dengan kemampuan berpikir tingkat tinggi tidak hanya mengujikan pada aspek ingatan atau hapalan saja melainkan menguji hingga pada aspek analisis, sintesis, dan evaluasi. Dari hasil analisis terhadap 20 butir soal, terdapat delapan soal yang termasuk kategori soal 
tipe LOTS yakni pada tingkat C1 - Mengingat (Remembering) yakni pada soal nomor 1, 2, 3, 13, dan 19. Pada tingkat C2 - Memahami (Understanding) yakni pada soal nomor 16 dan 18. Pada tingkat C3 - Mengaplikasikan (Applying) yakni pada soal nomor 10. Dan 12 soal termasuk kategori soal tipe HOTS yakni pada tingkat C4 - Menganalisis (Analyzing).

Pada tingkat C1 - Mengingat (Remembering), bentuk soalnya antara lain memahami makna kata (soal nomor 1), soal tentang mengidentifikasi sinonim (soal nomor 2), soal tentang mengidentifikasi pernyataan yang mengandung sebuah informasi yang sesuai dengan paragraf (soal nomor 3), soal tentang melengkapi data yang disajikan dalam bentuk tabel yang rumpang sesuai dengan jawaban yang berada dalam sebuah teks (soal nomor 13), dan soal menjelaskan maksud pernyataan pada sebuah cerita (soal nomor 19). Pada tingkat C2Memahami (Understanding), bentuk soalnya antara lain memahami makna yang bercetak miring pada cerita (soal nomor 16), dan mengemukakan tema yang terkandung dalam puisi (soal nomor 18).

Pada tingkat C3-Mengaplikasikan (Applying), bentuk soalnya antara lain mengklasifikasikan jenis paragraf (soal nomor 10). Pada tingkat C4 Menganalisis (Analyzing), bentuk soalnya antara lain menguraikann jawaban pertanyaan yang sesuai dengan sebuah kalimat (soal nomor 4), soal tentang menguraikan kalimat utama yang terdapat dalam teks (soal nomor 5), soal tentang menguraikan kalimat penjelas yang terdapat dalam teks (soal nomor 6), soal tentang menguraikan ide pokok yang terdapat dalam teks (soal nomor 7), soal tentang menyimpulkan teks (soal nomor 8), soal tentang mengidentifikasi pernyataan yang sesuai dengan teks (soal nomor 9), soal tentang menguraikan jawaban yang sesuai dengan pernyataan (soal nomor 11), soal tentang menguraikan persamaan dalam kedua teks (soal nomor 12), soal tentang menguraikan pernyataan sesuai dengan cerita (soal nomor 14), soal tentang menganalisis watak tokoh kelingking dalam cerita (soal nomor 15), soal tentang menentukan kesimpulan yang sesuai dengan cerita (soal nomor 17), soal tentang Menentukan kesimpulan dari sebuah cerita (soal nomor 20) 
Dari keseluruhan hasil analisis terhadap 20 butir soal objektif pilihan ganda, maka diperoleh dua belas butir soal yang termasuk dalam kriteria penilaian baik (soal nomor 4, 5, 6, 7, 8, 9, 11, 12, 14, 15, 17, 20), satu soal termasuk dalam kriteria cukup baik (soal nomor 10), dua soal termasuk dalam kriteria kurang baik (soal nomor 16 dan 18), dan lima soal termasuk kriteria tidak baik (soal nomor 1, 2, 3, 13, dan 19). Dari hasil analisis yang telah dilakukan oleh peneliti terhadap 20 butir soal USBN bahasa Indonesia SD/MI tahun pelajaran 2018/2019, soal tes objektif pilihan ganda yang dibuat oleh dinas pendidikan kota Madiun sebagian besar telah memenuhi kriteria pengembangan soal HOTS.

Hal ini terbukti dari 20 butir soal, 12 diantaranya termasuk kategori soal tipe HOTS pada kelas C4 - Menganalisis (Analyzing) dan 8 soal termasuk kategori soal tipe LOTS pada kelas C1 - Mengingat (Remembering), C2 Memahami (Understanding), C3 - Mengaplikasikan (Applying). Berdasarkan hasil presentase terhadap 20 butir soal tes objektif pilihan ganda USBN Bahasa Indonesia SD/MI tahun pelajaran 2018/2019, soal yang memiliki kriteria HOTS berjumlah 12 soal dengan presentase $60 \%$ dan soal yang memiliki kriteria LOTS sebanyak 8 soal dengan presentase $40 \%$. Jadi, dalam 20 butir soal tes objektif pilihan ganda USBN Bahasa Indonesia SD/MI tahun pelajaran 2018/2019 masih ditemukan soal berbasis LOTS dengan presentase $40 \%$, namun pada soal tersebut, soal dengan kriteria HOTS masih mendominasi dengan presentase $60 \%$.

\section{SIMPULAN}

Berdasarkan hasil analisis yang telah dilakukan terhadap 20 butir soal tes objektif pilihan ganda USBN Bahasa Indonesia SD/MI tahun pelajaran 2018/2019, dapat disimpulkan bahwa 12 soal yang termasuk ke dalam tipe soal HOTS dan 8 soal lainnya termasuk ke dalam tipe soal LOTS. Dari 12 butir soal yang memenuhi kriteria HOTS tersebut terdapat pada tingkat C4 - Menganalisis (Analyzing) dengan presentase $60 \%$ dan 8 soal termasuk kategori soal tipe LOTS pada kelas C1 - Mengingat (Remembering), C2 - Memahami (Understanding), C3 - Mengaplikasikan (Applying) dengan presentase 40\%. Dari hasil analisis 
yang telah dilakukan oleh peneliti, soal tes objektif pilihan ganda USBN bahasa Indonesia yang dibuat oleh dinas pendidikan kota Madiun sebagian besar telah memenuhi kriteria pengembangan soal HOTS.

\section{DAFTAR PUSTAKA}

Arikunto, S. (2012). Prosedur Penelitian Suatu Pendekatan Praktek.Jakarta: Rineka Cipta.

Brookhart S.M. (2010). How to Asses Higher Order Thinking Skills in Your Classroom. Alexandria: ASCD.

Devi, P,. K. (2011). Pengembangan Soal "Higher Order Thinking Skill” dalam Pembelajaran IPA SMP / MTs. [Online]. Diakses dari http://p4tkipa.net/data-jurnal/HOTs.Poppy.pdf

Leonard. (2013). Peran Kemampuan Berpikir Lateral dan Positif terhadap Prestasi Belajar Evaluasi Pendidikan. Cakrawala Pendidikan, 32 (1): 5463.

Lewis, A and Smith, D. (1993). Defining High Order Thingking Theory Into Practice Collage of Education. Ohio: The Ohio State University.

Majid, A. (2007). Perencanaan Pembelajaran: Mengembangkan StandarKompetensi Guru. Bandung: PT. Remaja Rosdakarya Offset.

Moleong, L. J. (2007). Metodologi Penelitian Kualitatif. Bandung: PT Remaja Rosdakarya.

Ratnawulan, E. dan Rusdiana. (2015). Evaluasi Pembelajaran. Bandung: CV. Pustaka Setia.

Sudaryono. (2012). Dasar-Dasar Evaluasi Pembelajaran. Yogyakarta: Graha Ilmu.

Zulmiati. (2017). Pengaruh Bentuk Tes Pilihan Ganda dan Teknik Penskoran terhadap Reabilits Soal Biologi Kelas X SMA Negeri Bulukumba. UNM online Journal Systems. 